\title{
Architectural Sustainability on the Impacts of Different Air- Conditioning Operational Profiles and Temperature Setpoints on Energy Consumption: Comparison between Mosques with and Without HVLS Fan in the City Center Mosques
}

\author{
Nur Amalina Syairah Mohamed ${ }^{1}$, Zalina Shari $^{1 *}$, Nur Dalilah Dahlan ${ }^{1}$, Ibiyeye Aminat Idowu ${ }^{2}$ \\ ${ }^{1}$ Department of Architecture, Faculty of Design and Architecture, Universiti Putra Malaysia, \\ Serdang Malaysia \\ ${ }^{2}$ Department of Architecture, Faculty of Environmental Sciences, Kaduna State University, \\ Kaduna, Nigeria \\ *zalinashari@upm.edu.my
}

\begin{abstract}
The use of air-conditioning (AC) in conjunction with high-volume, low-speed (HVLS) fans has become a trend in retrofitted mosque buildings in Malaysia to improve thermal comfort conditions. However, the energy impact of operating AC and HVLS fan simultaneously is unknown. This study compares the annual energy consumptions between mosques with and without HVLS fan installed and investigates the optimum temperature setpoints and operational profile to improve the mosques' energy efficiency. The Building Energy Intensity (BEI) comparison did not clearly show the superiority between the two groups in terms of energy performance. The study found that both studied mosques could produce around $1-4.9 \%$ energy reduction when the AC temperature setpoint was increased by $1{ }^{\circ} \mathrm{C}$ and could result in the highest cost-saving of about $4.9 \%$ when the temperature was set at $27^{\circ} \mathrm{C}$. A 30 -minute AC operation during each daily prayer, except Subuh, could save between $14.8-16.7 \%$ annual energy consumption and about 15.2-16.6\% annual energy cost. The paper concludes that the selection of $24-27^{\circ} \mathrm{C}$ temperature setpoints with a 30 -minute $\mathrm{AC}$ operational profile during prayers time, considering Friday prayers and Ramadhan activities, produced 18.4-20.6\% savings in energy cost. This study calls for reevaluations of AC temperature setpoints configuration standards and operational characteristics in mosque buildings to reduce energy consumption. This paper contributes to the development of future energy standards for mosque designs and operations in Malaysia.
\end{abstract}

Keywords: Temperature Setpoints, Operational Profile, Building Energy Intensity (BEI), HighVolume Low-Speed (HVLS) Fan, Air-Conditioning, Mosques, Malaysia 


\section{INTRODUCTION}

Mosques are a religious building type that is an essential part of any Muslim civil society. They are unique buildings in terms of their function and operation. Mosques are used not only for praying and religious purposes but also for community functions. Operationally, they are occupied intermittently for performing prayers five times a day, all year round. Each occupancy is either partial or full and lasts at the most for an hour. Worshippers do not usually arrive or leave the mosque simultaneously during this hour but rather at random. However, a maximum occupancy generally occurs during each prayer's actual performance, which lasts between 15 to 20 minutes. Some exceptions to this pattern of occupancy occur during weekly Friday prayers, the Taraweeh prayers during the nights of the month of Ramadhan (fasting month), and during other special occasions such as lecturing and seminar activities, where people tend to stay longer in the mosques (Al-Homoud et al., 2005a). Understanding the functions and operations of mosques reflect the importance of thermal design for occupants' comfortable praying experience. Intermittent occupancy means mosques may not perform thermally the same as typical commercial buildings. Installations of airconditioning ( $\mathrm{AC}$ ) systems in mosque buildings to achieve the required thermal comfort have become common in the hot and humid climate region, particularly in Malaysian urban areas (Department of Standards Malaysia, 2014; Hussin et al., 2014). AC systems are responsible for the significant percentage of energy consumption in buildings. Malaysia's building sector contributes $40.5 \%$ of total national energy consumption (Malaysia Energy Commission, 2019 ) and $43.4 \%$ of total carbon dioxide emissions (Mohd Safaai et al., 2011).

Recently, the use of AC system in conjunction with high-volume, low-speed (HVLS) fans to achieve the desired thermal comfort in the main prayer halls has become a common trend in mosques located in Malaysian urban areas, such as in Kuala Lumpur, Selangor and Johor (Othman et al., 2019; Yendo et al., 2015). As shown in Figure 1, the HVLS fan is a new generation of ceiling fan with a large fan diameter design that can cover a large area at a slow-motion speed (Moshfeghi et al., 2014). Specifically, it has airfoil blades measuring a minimum of 2.1-meter in diameter with a rotation in the range of 50-125 revolutions per minute to produce a minimum airflow of 140,000 cubic feet per minute (Moshfeghi et al., 2014). HVLS fan does not only provide comfort, but the fan's motor is also energy efficient (Shah et al., 2015). However, the extent to which the concurrent operation of both AC and HVLS fans affects the mosques' energy performance still remains unclear. Do these mosques achieve the required thermal comfort while consuming the least energy? This paper argues that when the operations of both $\mathrm{AC}$ system and HVLS fans are improperly designed, it could result in additional, unnecessary amounts of energy.

An AC system's ultimate goal is to provide better indoor thermal comfort for building occupants; hence, the system's proper operations must avoid energy wastage. The comfort level is higher when an air-conditioned room is integrated with a ceiling fan (Chen et al., 2020). The air movement created by the ceiling fan keeps the building's occupants feeling comfortable, although the setpoint temperature of the $\mathrm{AC}$ is high. A study by Wang and Lin (2013) found that $40 \%$ of energy saving can be achieved in an intelligent building using a smart control AC and ceiling fan. They explained that the airflow from a ceiling fan could provide a cooling sensation to the occupants. The strategy of increasing the AC thermostat temperature and adjusting the ceiling fan speed to the medium can help achieve a comfortable and energy-efficient environment (Hawaii Natural Energy Institute, 2017).

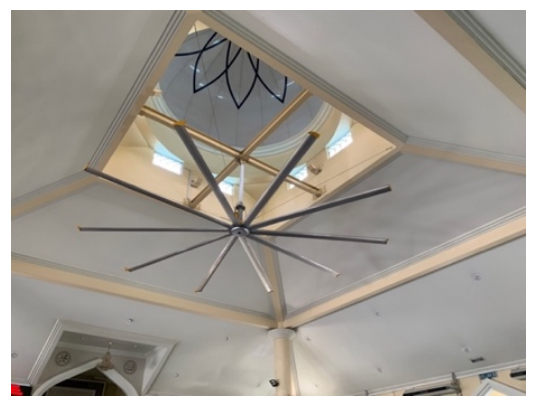

Figure 1: High-volume low-speed (HVLS) fan Source: Author

Currently, little information on energy performance or building energy intensity (BEI) of mosque buildings is available. An early study by Al-Homoud et al. (2005a) showed that the average BEI value of five mosques in Saudi Arabia was $167 \mathrm{kWh} / \mathrm{yr} / \mathrm{m}^{2}$. The figure increased to $181.9 \mathrm{kWh} / \mathrm{yr} / \mathrm{m}^{2}$ after the subsequent data collections and analyses (Al-Homoud et al., 2005b). In Malaysia, a recent study by Hussin et al. (2019) on five retrofitted air-conditioned mosques in Penang revealed that three of the mosques demonstrated BEI values of between 70 to $124 \mathrm{kWh} / \mathrm{yr} / \mathrm{m}^{2}$, which are lower than the BEI of office buildings by Saidur and Masjuki (130 $\mathrm{kWh} / \mathrm{yr} / \mathrm{m}^{2}$ ). The fourth mosque's BEI was 135 $\mathrm{kWh} / \mathrm{yr} / \mathrm{m}^{2}$, while the fifth was $323 \mathrm{kWh} / \mathrm{yr} / \mathrm{m}^{2}$, a 
significantly higher value than the BEI of hospitals $\left(244.8 \mathrm{kWh} / \mathrm{yr} / \mathrm{m}^{2}\right)$ by Moghimi et al. (2011). As Hussin et al. (2019) is so far the only study on mosque BEI in Malaysia, it was considered appropriate for their BEI values to be used as the baseline in this paper. The high BEI results from Al-Homoud et al. (2005b) and Hussin et al. (2019) highlight the need for more energy retrofit measures in mosque buildings. Although these studies focused on airconditioned mosques, they ignored the usage of HVLS fans.

Energy retrofit is one of the instruments used to improve buildings' energy performance (Rogeau et al., 2020). There are two types of energy retrofits: technical configurations and behavioural interventions (i.e. human-based retrofits). Technical configurations involve rearranging, replacing, adding and deleting some existing components of the buildings (Brown et al., 2014; Mancini \& Nastasi, 2019; Sánka \& Petráš, 2019). The discussion of this approach revolved around better bioclimatic designs and more energy-efficient insulation, windows and HVAC systems (Ariosto et al., 2019; Fang \& Cho, 2019; Jankovic, 2019). Technical configurations type of energy retrofits has been widely studied for schools (Ali \& Hashlamun, 2019; Tahsildoost \& Zomorodian, 2015), commercial (Li et al., 2020), offices (Mohamad et al., 2018; Somasundaram et al., 2020) and residential buildings (Friedman et al., 2014; Wu et al., 2017). Despite their advantages, such retrofit measures are complex as they involve large-scale modifications, high upfront capital cost, and long implementation time (Cajot et al., 2017; Mirakyan \& De Guio, 2013)

Behavioural intervention or human-based retrofits, on the other hand, refers to modifications of human (occupants or building managers) behaviour or actions that they can take to improve the existing building operation towards achieving energy efficiency (Ascione et al., 2020; Barthelmes et al., 2017; Pan et al., 2017). Examples of such actions include adjusting the HVAC thermostat setpoints, opening windows for natural ventilation, reducing the use of artificial lightings, equipment and appliances, to name a few (Dall'O' et al., 2012). Many studies have been conducted on behavioural intervention types of retrofits (Dall'O' et al., 2012). Human-based retrofits are generally more cost-effective (i.e. they come with little or no implementation costs) and practical than technical retrofits (Xia et al., 2019). However, the success depends on the occupantsbuilding interaction and the occupants' and management staff's level of commitment (Jami et al., 2020; Xu et al., 2013).

Among the behavioural interventions to reduce energy consumption are fine-tuning the $\mathrm{AC}$ temperature setpoints and revisiting the $\mathrm{AC}$ operational profiles. An adjustment to the $\mathrm{AC}$ temperature setpoints is made according to the desired indoor thermal comfort (Aghniaey \& Lawrence, 2018; Yan et al., 2019b), but research has shown that an increase of $1^{\circ} \mathrm{C}$ in $\mathrm{AC}$ temperature setpoint will reduce at least $7 \%$ of energy consumption (Ho et al., 2009). A growing number of studies conducted in hot climatic regions show that adjustments to the $\mathrm{AC}$ temperature setpoints significantly impact building energy consumption. These studies were conducted in Singapore (Tom, 2008; Tushar et al., 2016), Malaysia (Mustapa et al., 2017), Thailand (Yamtraipat et al., 2005), Indonesia (Hamzah et al., 2018; Sunardi et al., 2020) and South Africa (Wang et al., 2013). These studies have recommended different ranges of temperature setpoints for thermal comfort. Although there is no specific point when the effect of temperature is dissatisfactory in terms of thermal comfort to the users, controlling the AC temperature setpoints has been reported to be one of the means of managing the building energy consumption (Aghniaey \& Lawrence, 2018).

A reevaluation of the $\mathrm{AC}$ operational profile, on the other hand, involves strategising the $\mathrm{AC}$ operation schedule based on a deep understanding of the building usage, occupancy load, climate factors, and occupancy duration of the building (Knight, 2016; Xia et al., 2019; Yang \& Becerikgerber, 2014). For example, the AC operational profile for a mosque may differ from other building types as mosques generally have intermittent occupancy. Previous literature has also suggested that AC operating profiles are expected to significantly impact the mosques' thermal and energy performance (Al-Homoud et al., 2005b; Al-Shaaban \& Alohaly, 2017; Budaiwi \& Abdou, 2013; Omar et al., 2020). Furthermore, the effectiveness of the operational profile depends on the understanding of the $\mathrm{AC}$ response time and the amount of time needed for the AC system to cool down space to the temperature setpoint (Hui et al., 2017). The function and operational strategies of a mosque depend on the end-users, of whom the designers have no or less control (Atmaca \& Gedik, 2019; Hussin et al., 2019). Therefore, it is crucial to involve the end-users in implementing energy conservation measures without compromising the indoor environmental conditions of building users. It could be argued that behavioural interventions or human-based retrofits are more suitable for buildings with intermittent occupancy 
such as mosques than technical retrofits.

The evidence gathered here suggests that behavioural interventions through $\mathrm{AC}$ temperature setpoints and operational profile optimisations can achieve cooling energy reduction and thermal comfort improvement. It is also necessary to determine a suitable range of $\mathrm{AC}$ temperature setpoints and integrate the cooling duration into $\mathrm{AC}$ operating profiles of mosques in Malaysia. Moreover, there is a need for a clear understanding of the energy impacts of operating AC and HVLS fans in mosques and how behavioural interventions could be undertaken to minimise the energy consumption without compromising their indoor thermal comfort levels. To the best of our knowledge, there is no academic paper in the building literature that focuses on this aspect. This paper aims to fill this gap. The objectives of this paper are 1) to analyse and compare the BEI between air-conditioned mosques with and without HVLS fan, and 2) to assess the energy-saving potential of air-conditioned mosques through different $\mathrm{AC}$ temperature setpoints and operational profiles adjustments. The findings motivate the need to revisit $\mathrm{AC}$ setpoint configuration and operational profile standards in mosque buildings, either as a segment of individual building retrofit preparation or as a segment of energy standards for mosque designs and operations in Malaysia.

This paper is structured as follows. The second part of the paper reviews the recent studies on the proper use and control of AC systems for energy efficiency and HVLS fans' applications for thermal comfort. The third part discusses the study's methodological details, which comprise the techniques in selecting the mosques, collecting the electricity bills, and conducting energy simulations. The comparison of BEI results between mosques with and without HVLS fans through behavioural interventions is presented in the fourth section, whilst the fifth section discusses their implications and existing limitations. Finally, the paper concludes with a summary of the essential findings and recommendations for future work.

\section{METHODOLOGY}

\subsection{Site Description and Mosque Selection}

The mosques selected for the study are located in the Klang Valley (lying between $2.6817^{\circ} \mathrm{N}$ and $\left.101.6813^{\circ} \mathrm{E}\right)$, an urban conglomeration in Malaysia centred in Kuala Lumpur. Klang Valley includes adjoining cities and towns in Selangor, namely, Klang, Hulu Langat, Gombak,
Sepang and Petaling Jaya. Malaysia's climate is categorised as hot and humid throughout the year, with the mean radiant temperature of $28^{\circ}$ and the average highest daytime temperature of $38^{\circ} \mathrm{C}$. The relative humidity ranges between $65 \%$ to $90 \%$, with the annual rainfall between $1800 \mathrm{~mm}$ and $3900 \mathrm{~mm}$. Generally, Malaysia's climate characteristics are uniform temperature, high humidity, light wind, and copious rainfall (Malaysia Meteorological Department, 2019). All countries in the Southeast Asia region have the same tropical climate type (Mcknight \& Hess, 2000).

As of 2019, there were 6,446 mosques in Malaysia, 396 of which were located in Selangor, and 71 in Kuala Lumpur. The number of mosques is expected to increase due to the growth of the Muslim population in Malaysia (Department of Statistic Malaysia, 2019). About $70 \%$ of the mosques in Malaysia can accommodate between 1000 to 3500 worshippers at a time (Department of Islamic Development Malaysia, 2020). Therefore, the mosques of this size were selected for this study. Although a mosque can generally accommodate 3000 people, the calculation of area per worshipper revealed that the main praying hall could only hold about 550 worshippers (Malaysia Economic Planning Unit, 2015). Architecturally, mosques are generally rectangular in plan with walled enclosures, windows and a prominent roof above the main prayer hall. The building height varies from one to three stories, with a void above the prayer hall.

\subsection{Case Studies: Selection Parameters, Instrumentation and Limits}

The selection of specific mosques for the study was based on the following parameters: 1) located in areas with the same weather profile and prayer times, 2) no older than 20 years old, 3) built with similar building materials, 4) have similar operational profiles and use split-unit AC system type in the main prayer halls, and 5) able to provide two years of electricity bill data (January 2017 to December 2018). The study identified 54 mosques that met the research parameters 1 and 2. In order to confirm parameters 3 and 4, site visits were conducted to all 54 mosques. During the visits, the survey form by Ibrahim (2015) was used to record data of the mosques. The survey form contained three sections. The first section recorded the general building information such as roof type, year of construction, total area and total praying hall area, dimensions of the mosque, window types, and any internal shading used. The second section recorded the building operation schedules, including the zoning of the mosque, 
air-conditioned area and the type of verandah. The final section required inputs on the descriptions of the building energy usage such as the type of lighting system, type of AC system, types of fans, power distribution panel, and socket points. Floor plans were sketched in the form if drawings were not available.

The study finally confirmed that the 54 identified mosques met the research parameters $1-4$, and they were classified into two groups, i.e., mosques with HVLS fan (Group A: 14 nos.) and those without HVLS fans (Group B: 40 nos.). However, due to time and cost constraints and some restrictions in obtaining permission from the mosques' management, only three mosques from each group were selected. Their general descriptions are shown in Table 1. These six mosques were considered representative. They met all the selection parameters, including parameter 5. Floor plans were obtained except for two mosques (A3 and B3), of which detailed measurements had to be conducted due to the nonexistence of architectural drawings. More site visits were conducted to all these six mosques. Specifically, detailed walk-throughs were performed to understand the mosques' layout and identify the cooling areas and parts of the buildings that differed from the original building plans. Interviews with the mosques' administration staff were carried out to have insights into the mechanical ventilation operations.

\subsection{Comparison of energy consumption and cost}

The Building Energy Intensity (BEI) was calculated to compare the energy consumption levels among the selected mosques and between the mosques and the Malaysian Standard (MS1525: 2019)(Department of Standards Malaysia, 2019) as well as results from previous studies on mosques. In light of the lack of green mosques in Malaysia, the study used the Malaysia Standard (MS1525: 2019) and previous studies as the basis of comparison. MS1525 stated that the BEI for office buildings should be less than 200 $\mathrm{kWh} /$ year $/ \mathrm{m}^{2}$, while Moghimi et al. (2011) revealed the BEI for hospital buildings is 245 $\mathrm{kWh} /$ year $/ \mathrm{m}^{2}$. Since mosques do not have a similar cooling floor area, energy consumption and energy cost need to be generalised. The usage of AC relatively affects the thermal comfort of the occupants. Therefore, the variables that affect the mosques' cooling load and indoor thermal comfort were considered in this study. Any sensible heat gain and latent heat gain, lightings, fans, computers and plug points were considered. The U-value of the mosques' walls, roof materials, and opening types were also recorded.

This study adopted the formula by Saidur and Masjuki (2008) to calculate the Energy Intensity Index (ACEII) in $\mathrm{kW} / \mathrm{m}^{2} / \mathrm{yr}$, as shown below:

$$
A C E I I=\frac{\sum_{i}^{n} A E C}{C F A}
$$

where AEC is the total value of energy consumption of equipment $i$ to $n$ and CFA is the cooling floor area $\left(\mathrm{m}^{2}\right)$. The air conditioning cost index (ACCI) in $\mathrm{RM} /$ year $/ \mathrm{m}^{2}$ was estimated using the following equation:

$$
A C C I=\frac{\sum_{i}^{n} A C E}{C F A}
$$

where the ratio is the sum of energy consumed in Malaysia Ringgit (RM) to the cooling floor area $\left(\mathrm{m}^{2}\right)$ (Saidur \& Masjuki, 2008).

Three mosques using HVLS fan (Group A) and three mosques without HVLS fan (Group B) were selected as case studies. Although the sample size is small, the results would help the mosques' management to make wise decisions on energy conservation measures. The BEI values of mosques in both groups were calculated by using two-year electricity bill data (January 2017 to December 2018) and formula equations (1)(2) above.

\subsection{Data Analysis}

The values of the normalised total energy consumption and cost of all mosques were analysed by using SPSS statistical software. All data on energy used (kWh) and cost (RM), which were generalised for two years, were keyed in. Data of each mosque were sorted according to months and years. Later two separate independent sample t-tests were performed to compare mosques in both groups regarding energy consumption and cost within a two-year timeframe. Each mosque in group A was compared to the other three mosques in group B, resulting in $9 \mathrm{t}$-tests for each group, hence, $18 \mathrm{t}$ tests in total. The independent t-test results determined whether the two groups of mosques are statistically different in terms of their level of energy consumption. This was made by producing a statistical mean (i.e. the average used to derive the central tendency of the data for two years). The annual mean values of electricity consumption and cost of all mosques were generated, compared and ranked using the SPSS software. From the ranking, the mosque with the highest "mean energy consumption" and "mean energy cost" was selected to represent each group. The hypothesis for the t-test is explained in the 
result section.

\subsection{Energy Simulation}

The mosque with the highest BEI from each group was simulated using IESVE Software to determine the best temperature setpoints and operational profile that resulted in the most significant reduction in energy consumption. The simulation's input data include the building's geographical location, the three-dimensional geometry form and orientation, the building materials' thermal abilities, the type and efficiencies of the cooling and lighting elements, and the internal gains from electrical appliances and building occupants. These data were obtained from the architectural drawings and official construction plans. The occupants' energy usage data were gathered from the interviews that asked about their daily prayers routines.

The data were subsequently drawn in Model IT before the main module software ApacheSim was used to perform the numerous dynamic thermal simulations. The software also allowed the customisation of lighting, equipment, and occupancy profiles based on the internal heat gain value. This study utilised the default settings of "one occupant per $1.4 \mathrm{~m}^{2}$ floor area" for the occupancy and $70 \mathrm{~W} /$ person for the sensible heat gain. In the ApacheSim module, the building's specific construction elements were built based on the specification data gathered during the walk-through audit. Building areas were grouped according to their thermal zones, i.e. airconditioned or non-air-conditioned areas. A oneyear period of electricity bill data of both case studies was used to validate the model, hence establishing reasonable confidence in the simulation results. The operational profile used for the simulation reflected the existing occupancy patterns of the mosques, i.e. five times daily prayers, Friday prayers, and Ramadhan month timings. The operational profile also took into account the lightings, fans and air conditioners used in the buildings. Both mosques used split units AC with different capacities. The size of the air-conditioners used was assumed to be adequate for the total area covered. The temperature setpoint was recorded at $19^{\circ} \mathrm{C}$. External climatic data used in the simulation were real data obtained from the Malaysian Meteorological Department. A simulation period of one year was selected with a simulation time step of 10 minutes, a reporting interval of 60 minutes, and a preconditioning period of 10 days, as recommended in the IESVE guidelines.

\section{RESULTS}

\subsection{Energy consumption and cost impact using Building Energy Intensity (BEI)}

Figure 2 shows the BEI value of each mosque. Although the highest BEI is a mosque from group $\mathrm{A}$, the second highest is from group B. The two mosques that had exhibited the highest BEI values were A1 (Wangsa Melawati Mosque) and B2 (UTM Mosque), with the values of 230 $\mathrm{kW} / \mathrm{m}^{2} / \mathrm{yr} 191 \mathrm{~kW} / \mathrm{m}^{2} / \mathrm{yr}$, respectively. The lowest BEI among the six case studies was produced by mosque A3 (Alam Damai Mosque.

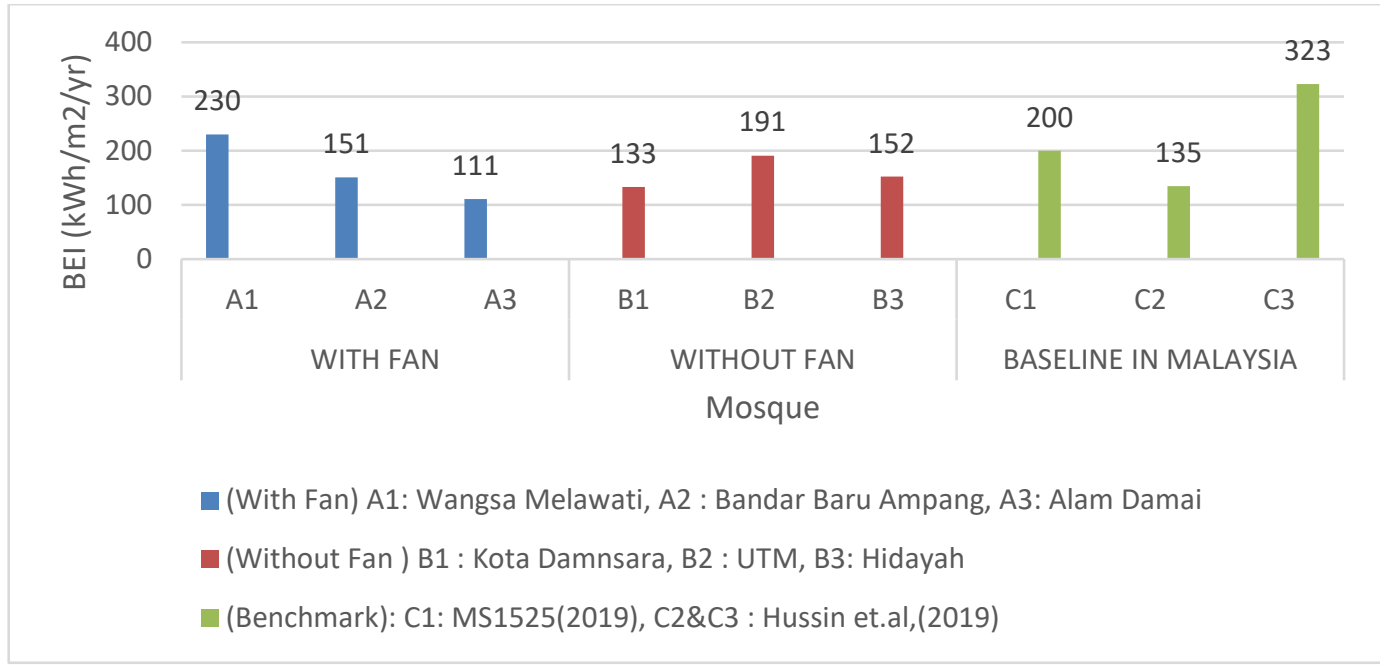

Figure 2: Building Energy Intensity (BEI) of the six studied mosques 
Table 1: Selected six mosques as case studies

\begin{tabular}{|c|c|c|c|c|c|c|}
\hline & \multicolumn{3}{|c|}{ GROUP A: WITH HVLS FAN } & \multicolumn{3}{|c|}{ GROUP B: WITHOUT HVLS FAN } \\
\hline Code and name & $\begin{array}{c}\text { A1: Wangsa } \\
\text { Melawati Mosque }\end{array}$ & $\begin{array}{l}\text { A2: Bandar Baru } \\
\text { Ampang Mosque }\end{array}$ & $\begin{array}{l}\text { A3: Alam Damai } \\
\text { Mosque }\end{array}$ & $\begin{array}{l}\text { B1: Kota Damansara } \\
\text { Mosque }\end{array}$ & B2: UTM Mosque & B3: Hidayah Mosque \\
\hline \multicolumn{7}{|l|}{$\begin{array}{l}\text { Image } \\
\text { (Source : Author) }\end{array}$} \\
\hline Location & $\begin{array}{l}\text { Wangsa Melawati, } \\
\text { Kuala Lumpur }\end{array}$ & Ampang, Selangor & Cheras, Selangor & Petaling, Selangor & Kuala Lumpur & $\begin{array}{l}\text { Sg. Penchala } \\
\text { Kuala Lumpur }\end{array}$ \\
\hline $\begin{array}{l}\text { Total floor area } \\
\left(\mathrm{m}^{2}\right)\end{array}$ & 930 & 1669 & 2120 & 2226 & 2818 & 2672 \\
\hline $\begin{array}{l}\text { Total cooling } \\
\text { Area }\left(\mathbf{m}^{2}\right)\end{array}$ & 550 & 712 & 700 & 1122 & 919 & 784 \\
\hline No. of storey & $11 / 2$ & 1 & 2 & $11 / 2$ & $11 / 2$ & 2 \\
\hline Roof material & $\begin{array}{l}\text { Metal dome on Flat } \\
\text { roof with } 6 \mathrm{~mm} \\
\text { perimeter floating } \\
\text { glass }\end{array}$ & $\begin{array}{l}\text { Metal dome roof on } \\
\text { metal pitch roof with } \\
6 \mathrm{~mm} \text { perimeter floating } \\
\text { glass }\end{array}$ & $\begin{array}{l}\text { Metal dome on Flat } \\
\text { roof with } 6 \mathrm{~mm} \\
\text { perimeter floating } \\
\text { glass }\end{array}$ & $\begin{array}{c}\text { Metal dome roof on } \\
\text { metal pitch roof with } \\
6 \mathrm{~mm} \text { perimeter floating } \\
\text { glass }\end{array}$ & $\begin{array}{l}\text { Metal dome on Flat } \\
\text { roof with } 6 \mathrm{~mm} \\
\text { perimeter floating } \\
\text { glass }\end{array}$ & $\begin{array}{l}\text { Metal dome on Flat } \\
\text { roof with } 6 \mathrm{~mm} \\
\text { perimeter floating } \\
\text { glass }\end{array}$ \\
\hline $\begin{array}{l}\text { Type of } \\
\text { construction }\end{array}$ & \multicolumn{6}{|c|}{ Brick wall and plaster } \\
\hline Window type & \multicolumn{6}{|c|}{ Three-sided perimeter casement/louvres and three-sided sliding door } \\
\hline Verandah & \multicolumn{6}{|c|}{ Three-sided verandah } \\
\hline Fan & \multicolumn{6}{|c|}{ Ceiling, wall and stand fans } \\
\hline AC type & \multicolumn{6}{|c|}{ Wall type, approximately 32 horse power } \\
\hline Lighting System & \multicolumn{6}{|c|}{ Dominated by fluorescent lighting } \\
\hline
\end{tabular}

25 Journal of Design and Built Environment, Vol 21(2) 19-38, August 2021 Mohamed et al. 
Table 2 compares the BEI values from this study with the previous studies by a few scholars. It is interesting to note that the BEI values of these two mosques are higher than those reported by Al-
Homoud, et al., i.e. $167 \mathrm{~kW} / \mathrm{m}^{2} /$ year (Al-Homoud et al., 2005a) and $181.9 \mathrm{~kW} / \mathrm{m}^{2} / \mathrm{yr}$ (Al-Homoud et al., 2005b), and by Hussin et al. (2019), i.e. 135 $\mathrm{kW} / \mathrm{m}^{2} / \mathrm{yr}$.

Table 2 : Results of Building Energy Intensity (BEI) and cost

\begin{tabular}{|c|c|c|c|c|c|}
\hline Description & $\mathbf{R M} / \mathbf{y r}$ & $\mathbf{k W h} / \mathbf{y r}$ & CFA & ACCI & $\begin{array}{l}\text { Average BEI } \\
\left(\mathrm{kW} / \mathrm{m}^{2} / \mathbf{y r}\right)\end{array}$ \\
\hline \multicolumn{6}{|c|}{ Mosques from this Study (Group A: With HVLS fan) } \\
\hline A1: Wangsa Melawati Mosque & 70,399 & 133,502 & 550 & 128 & 230 \\
\hline A2: Bandar Baru Ampang Mosque & 64,936 & 10,467 & 712 & 91.2 & 151 \\
\hline A3: Alam Damai Mosque & 38,884 & 76,741 & 700 & 55.6 & 111 \\
\hline \multicolumn{6}{|c|}{ Mosques from this Study (Group B: Without HVLS fan) } \\
\hline B1: Kota Damansara Mosque & 70,454 & 148,945 & 1122 & 62.8 & 133 \\
\hline B2: UTM Mosque & 93,601 & 177,693 & 919 & 101.9 & 191 \\
\hline B3: Hidayah Mosque & 66,680 & 122,026 & 784 & 85.1 & 152 \\
\hline \multicolumn{6}{|l|}{ Mosques from Other Studies } \\
\hline \multicolumn{6}{|l|}{ Hussin et al. (2019): } \\
\hline - Mosque 5 (centralised AC) & & & & 152.8 & 323 \\
\hline Al-Homoud et al. (2009) & & & & & $<202$ \\
\hline Al-Homoud et al. (2005a) & & & & & 167 \\
\hline Al-Homoud et al. (2005b) & & & & & 181.9 \\
\hline $\begin{array}{l}\text { MS1525: } 2019 \text { (Department of Standards Malaysia, } \\
\text { 2019) }\end{array}$ & & & & & 200 \\
\hline Moghimi et.al (2011) & & & & & 245 \\
\hline $\begin{array}{l}\text { Note: } C F A=\text { Cooling Floor Area; } A C C I=\text { Air Cond } \\
\text { The exchange rate of Malaysia Ringgit to U.S. Dolla }\end{array}$ & $\begin{array}{l}\text { ng Cost } \\
0.24 \text { (as }\end{array}$ & 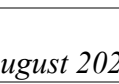 & & & \\
\hline
\end{tabular}

\subsection{Comparison of Mosque in terms of Energy Consumption and Cost}

The independent t-tests were conducted to determine whether the two groups of mosques differed regarding the level of energy consumption. The results of the energy consumption comparisons, i.e. the $p$-values produced by independent t-tests, associated with the six mosques identified the most energyefficient air-conditioned mosque. The assumed hypothesis of the t-tests is as follows:

Null hypothesis $\left(\mathrm{H}_{0}\right)$ : The two compared buildings $\left(\mu_{1}=\mu_{2}\right)$ are equal in energy consumption, therefore $\mathrm{H}_{0}: \mu_{1}=\mu_{2}$

Alternative hypothesis $\left(\mathrm{H}_{1}\right)$ : The two compared buildings are unequal in energy consumption, therefore $\mathrm{H} 1: \mu_{1} \neq \mu_{2}$

The t-test results of the electricity cost comparison associated with the six mosques identified the most energy-efficient mosque. Similar to the energy consumption comparisons, the electricity cost comparisons also involved nine separate $t$ tests.
The t-test results of energy consumption in Table 3 show that seven pairs of compared mosques had $p$-value $<0.05$; hence, the null hypothesis was rejected. This indicates that there were statistically significant differences in energy consumptions between the compared mosques. However, the comparison between A2 (Bandar Baru Ampang Mosque) and B1 (Kota Damansara Mosque), as well as A2 (Bandar Baru Ampang Mosque) and B3 (Hidayah Mosque), resulted in $p$-value $>0.05$; hence the null hypothesis was accepted, indicating that the differences in energy consumptions were negligible. Regarding the t-test results of energy costs, Table 3 indicates that there were statistically significant differences between all compared mosques ( $p$-values $<0.05)$, except between mosque A2 (Bandar Baru Ampang Mosque) and mosque B3 (Hidayah Mosque), where the difference was negligible ( $p$-value $>0.05)$.

Based on the mean values presented in Table 3, a ranking of the mosques is shown in Table 4, where number " 1 " indicates the best mosque and number "6" indicates the worst mosque in terms of mean energy consumption and cost. The ranking is a subjective ranking of the annual mean of energy consumption and cost. Table 4 shows that the ranking based on energy consumption is similar to 
the ranking based on energy cost. This similarity is unsurprising since energy consumption is closely related to energy cost. Interestingly, both the best and the worst mosques, namely, A3 (Alam Damai Mosque) and A1 (Wangsa Melawati Mosque), respectively, were mosques with HVLS fans. However, the second-best mosque was a mosque without the HVLS fan, i.e. B1 (Kota Damansara Mosque). This unclear pattern of rankings between mosques with and without HVLS fans may be due to different AC and fan operation profiles used.

Table 3 : T-tests results of energy consumption and cost

\begin{tabular}{|c|c|c|c|c|c|c|}
\hline \multirow{2}{*}{$\begin{array}{l}\text { HYPOTHESIS } \\
\text { (MOSQUES) }\end{array}$} & \multicolumn{3}{|c|}{$\begin{array}{l}\text { RESULTS FOR ENERGY } \\
\text { CONSUMPTION }\end{array}$} & \multicolumn{3}{|c|}{ RESULTS FOR ENERGY COST } \\
\hline & \multicolumn{2}{|c|}{$\begin{array}{c}\text { Mean } \\
\text { (Standard } \\
\text { Deviation) }\end{array}$} & \multirow[t]{2}{*}{$\begin{array}{c}\text { Probability } \\
(p \text {-value })\end{array}$} & \multicolumn{2}{|c|}{$\begin{array}{c}\text { Mean } \\
\text { (Standard Deviation) }\end{array}$} & \multirow[t]{2}{*}{$\begin{array}{c}\text { Probability } \\
\text { ( } p \text {-value) }\end{array}$} \\
\hline A1 and $B 1$ & A1 & B1 & & A1 & B1 & \\
\hline $\begin{array}{l}\text { Wangsa Melawati Mosque and Kota } \\
\text { Damansara Mosque }\end{array}$ & $\begin{array}{c}19.2 \\
( \pm 1.91)\end{array}$ & $\begin{array}{c}11.0 \\
( \pm 2.2)\end{array}$ & 0.001 & $\begin{array}{c}10.3 \\
( \pm 1.00)\end{array}$ & $\begin{array}{c}5.4 \\
( \pm 1.03)\end{array}$ & 0.001 \\
\hline A1 and $B 2$ & A1 & B2 & & A1 & B2 & \\
\hline Wangsa Melawati Mosque and UTM Mosque & $\begin{array}{c}19.2 \\
( \pm 1.91)\end{array}$ & $\begin{array}{c}17.3 \\
( \pm 2.12)\end{array}$ & 0.001 & $\begin{array}{c}10.3 \\
( \pm 1.00)\end{array}$ & $\begin{array}{c}8.6 \\
( \pm 1.01)\end{array}$ & 0.001 \\
\hline A1 and $B 3$ & A1 & B3 & & A1 & B3 & \\
\hline $\begin{array}{l}\text { Wangsa Melawati Mosque and Hidayah } \\
\text { Mosque }\end{array}$ & $\begin{array}{c}19.2 \\
( \pm 1.91)\end{array}$ & $\begin{array}{c}12.6 \\
( \pm 3.33)\end{array}$ & 0.001 & $\begin{array}{c}10.3 \\
( \pm 1.00)\end{array}$ & $\begin{array}{c}7.3 \\
( \pm 1.44)\end{array}$ & 0.001 \\
\hline$A 2$ and $B 1$ & $\mathrm{~A} 2$ & B1 & & $\mathrm{A} 2$ & B1 & \\
\hline $\begin{array}{l}\text { Bandar Baru Ampang Mosque and Kota } \\
\text { Damansara Mosque }\end{array}$ & $\begin{array}{c}12.6 \\
( \pm 3.31)\end{array}$ & $\begin{array}{c}11.0 \\
( \pm 2.22)\end{array}$ & 0.06 & $\begin{array}{c}6.9 \\
( \pm 1.55)\end{array}$ & $\begin{array}{c}5.4 \\
( \pm 1.02)\end{array}$ & 0.001 \\
\hline$A 2$ and $B 2$ & A2 & B2 & & A2 & B2 & \\
\hline $\begin{array}{l}\text { Bandar Baru Ampang Mosque and UTM } \\
\text { Mosque }\end{array}$ & $\begin{array}{c}12.6 \\
( \pm 3.31)\end{array}$ & $\begin{array}{c}17.3 \\
( \pm 2.13)\end{array}$ & 0.001 & $\begin{array}{c}6.9 \\
( \pm 1.55)\end{array}$ & $\begin{array}{c}8.6 \\
( \pm 1.02)\end{array}$ & 0.001 \\
\hline$A 2$ and $B 3$ & $\mathrm{~A} 2$ & B3 & & A2 & B3 & \\
\hline $\begin{array}{l}\text { Bandar Baru Ampang Mosque and Hidayah } \\
\text { Mosque }\end{array}$ & $\begin{array}{c}12.6 \\
( \pm 3.31)\end{array}$ & $\begin{array}{c}12.6 \\
( \pm 3.33)\end{array}$ & 1.00 & $\begin{array}{c}6.9 \\
( \pm 1.55)\end{array}$ & $\begin{array}{c}7.3 \\
( \pm 1.45)\end{array}$ & 0.35 \\
\hline A3 and B1 & A3 & B1 & & A3 & B1 & \\
\hline $\begin{array}{l}\text { Alam Damai Mosque and Kota Damansara } \\
\text { Mosque }\end{array}$ & $\begin{array}{c}9.3 \\
( \pm 0.96)\end{array}$ & $\begin{array}{c}11.0 \\
( \pm 2.22)\end{array}$ & 0.001 & $\begin{array}{c}4.9 \\
( \pm 0.54)\end{array}$ & $\begin{array}{c}5.4 \\
( \pm 1.03)\end{array}$ & 0.04 \\
\hline$A 3$ and $B 2$ & A3 & B2 & & A3 & $\mathrm{B} 2$ & \\
\hline Alam Damai Mosque and UTM Mosque & $\begin{array}{c}9.3 \\
( \pm 0.96)\end{array}$ & $\begin{array}{c}17.3 \\
( \pm 2.13)\end{array}$ & 0.001 & $\begin{array}{c}4.9 \\
( \pm 0.54)\end{array}$ & $\begin{array}{c}8.5 \\
( \pm 1.01)\end{array}$ & 0.001 \\
\hline $\mathrm{A3}$ and $\mathrm{B3}$ & A3 & B3 & & A3 & B3 & \\
\hline Alam Damai Mosque and Hidayah Mosque & $\begin{array}{c}9.3 \\
( \pm 0.96) \\
\end{array}$ & $\begin{array}{c}12.6 \\
( \pm 3.33) \\
\end{array}$ & 0.001 & $\begin{array}{c}4.9 \\
( \pm 0.54) \\
\end{array}$ & $\begin{array}{r}7.3 \\
( \pm 1.44) \\
\end{array}$ & 0.001 \\
\hline
\end{tabular}

Table 4 : Ranking of mosques in terms of energy consumption and cost

\begin{tabular}{clccc}
\hline Ranking & \multicolumn{1}{c}{ Building Name } & HVLS Fan & $\begin{array}{c}\text { Mean } \\
\text { (Energy Consumption) }\end{array}$ & $\begin{array}{c}\text { Mean } \\
\text { (Energy Cost) }\end{array}$ \\
\hline $\mathbf{1}$ & A3: Alam Damai Mosque & Yes & 9.3 & 4.9 \\
$\mathbf{2}$ & B1: Kota Damansara Mosque & No & 11.0 & 5.4 \\
$\mathbf{3}$ & A2: Bandar Baru Ampang Mosque & Yes & 12.6 & 6.9 \\
$\mathbf{4}$ & B3: Hidayah Mosque & No & 12.6 & 7.3 \\
$\mathbf{5}$ & B2: UTM Mosque & No & 17.3 & 8.6 \\
$\mathbf{6}$ & A1: Wangsa Melawati Mosque & Yes & 19.2 & 10.3 \\
\hline
\end{tabular}

Subsequently, the mosque with the highest energy consumption and cost from each group was brought into the simulation process to determine the best operational profiles and temperature setpoints to improve its energy efficiency. Therefore, A1 (Wangsa Melawati Mosque), ranked last in energy consumption and cost, and B2 (UTM Mosque), ranked fifth, were chosen to represent a mosque with and without HVLS fan, respectively.

\subsection{Validation of Stimulation Models}

Before the simulations on temperature setpoints and operational profiles were conducted, the developed models were validated by comparing the simulated monthly annual energy consumption results with the mosques' actual energy consumption, i.e. monthly annual electricity bills for 2017 . The results showed that

27 Journal of Design and Built Environment, Vol 21(2) 19-38, August 2021 Mohamed et al. 
the simulated energy profile was not more than $8.4 \%$ of the actual electricity bills; hence, the models were validated, and there was good confidence that the simulation results would be reliable and valid.

\subsection{Energy Simulation Result On Temperature Setpoints}

According to the actual usage, the temperature setpoint for A1 (Wangsa Melawati Mosque) and B2 (UTM Mosque) was set at $19^{\circ} \mathrm{C}$; hence, used as a baseline for this study. From this baseline temperature, it was increased at $1^{\circ} \mathrm{C}$ to up to $27^{\circ} \mathrm{C}$.
The resulted energy consumption, BEI and energy cost from each $1^{\circ} \mathrm{C}$ temperature increment for both mosques are summarised in Table 5 . Only the temperature setpoints were increased for this simulation, while the baseline AC operational profile remained the same. The results showed that the total energy and cost savings for Wangsa Melawati Mosque were 4.6\% and RM3106.00, respectively. For UTM Mosque, the respective total energy and cost savings were $3.8 \%$ and RM3456.00. It appears that the adjustment to AC temperature setpoints could result in higher energy and cost savings for A1 (Wangsa Melawati Mosque) than B2 (UTM Mosque)

Table 5 : Simulation results based on different temperature setpoints for Wangsa Melawati Mosque and UTM Mosque

\begin{tabular}{|c|c|c|c|c|c|c|c|c|c|}
\hline \multicolumn{10}{|c|}{ A1: Wangsa Melawati Mosque (with HVLS fan) } \\
\hline $\begin{array}{l}\text { Temperature } \\
\text { setpoint }\left({ }^{\circ} \mathrm{C}\right)\end{array}$ & $19^{\circ} \mathrm{C}$ & $20^{\circ} \mathrm{C}$ & $21^{\circ} \mathrm{C}$ & $22^{\circ} \mathrm{C}$ & $23^{\circ} \mathrm{C}$ & $24^{\circ} \mathrm{C}$ & $25^{\circ} \mathrm{C}$ & $26^{\circ} \mathrm{C}$ & $27^{\circ} \mathrm{C}$ \\
\hline $\begin{array}{l}\text { Total Energy } \\
\text { Consumption } \\
(\mathrm{kWh})\end{array}$ & 119,343 & 118,655 & 117,889 & 117,122 & 116,350 & 115,577 & 114,780 & 114,035 & 113,325 \\
\hline Cooling area (m2) & 550 & 550 & 550 & 550 & 550 & 550 & 550 & 550 & 550 \\
\hline $\mathrm{BEI}\left(\mathrm{kWh} / \mathrm{yr} / \mathrm{m}^{2}\right)$ & 216 & 215 & 214 & 213 & 212 & 210 & 209 & 207 & 206 \\
\hline$\%$ BEI Saving & - & 0.5 & 0.9 & 1.4 & 1.9 & 2.8 & 3.2 & 4.2 & 4.6 \\
\hline Cost (RM) & 60,901 & 60,513 & 60,213 & 59,732 & 59,338 & 58,944 & 58,547 & 58,157 & 57,795 \\
\hline Saving (RM) & - & 388 & 688 & 1169 & 1563 & 1957 & 2354 & 2744 & 3106 \\
\hline \multicolumn{10}{|c|}{ B2: UTM Mosque (without HVLS fan) } \\
\hline $\begin{array}{l}\text { Total Energy } \\
\text { Consumption } \\
(\mathrm{kWh})\end{array}$ & 171,269 & 170,434 & 169,597 & 168,754 & 167,909 & 167,057 & 166,205 & 165,353 & 164,493 \\
\hline Cooling area $(\mathrm{m} 2)$ & 919 & 919 & 919 & 919 & 919 & 919 & 919 & 919 & 919 \\
\hline BEI (kWh/yr/m²) & 186 & 185 & 184 & 183 & 182 & 182 & 181 & 180 & 179 \\
\hline$\%$ BEI Saving & - & 0.5 & 1.1 & 1.6 & 2.2 & 2.2 & 2.7 & 3.2 & 3.8 \\
\hline Cost (RM) & 87,347 & 86,921 & 86,494 & 86,064 & 85,633 & 85,198 & 84,764 & 84,330 & 83,891 \\
\hline Saving (RM) & - & 426 & 853 & 1283 & 1714 & 2149 & 2583 & 3017 & 3456 \\
\hline
\end{tabular}

\subsection{Occupancy Profile}

Understanding a building's occupancy profile or pattern is important in scheduling the building's $\mathrm{AC}$ operation. The uniqueness of mosque buildings is seen from their intermittent occupancy profile, primarily based on prayer times. The operational profiles of the Wangsa Melawati Mosque and UTM Mosque are similar, as explained below. It is important to note that the AC operational profile of both studied mosques also included the mosques' administration office because the space was airconditioned and operated daily from 8:00 to
17:00 except for Saturday, Sunday and public holidays.

The baseline AC operation profiles are grouped according to the three occupancy profiles as follows:

1. Daily profile: This was according to the five prayer times, namely Subuh (dawn, before sunrise, 5:30 to 6:30), Zohor (midday, after the sun passes its highest, 12:30 to 13:30), Asar (the late part of the afternoon, 16:00 to 17:00), Maghrib and Isyak (between sunset and midnight, 19:00 to 21:00). 
2. Friday profile: This was similar to the daily profile except during Zohor from12:30 to $15: 00$, which is longer in duration to accommodate Friday's sermon.

3. Ramadhan profile: This had different daily operation time during Zohor, Maghrib and Isyak. Most worshippers would spend some time during the Zohor hours in the month of Ramadhan for itikaf (period of retreat in a mosque) or tadarus (recite Quran in a group). Therefore, the operations time of Zohor during Ramadhan is 12:30 until 14:00. The operation time for Maghrib and Isyak are continuous from sunset until almost midnight (19:00 to 23:00). This is because worshippers begin to break their fast at the mosque during Maghrib and continue with Isyak prayer, followed by Tarawikh prayer (additional prayer after Isyak prayer).

It is of paramount importance to understand the outdoor air temperature and building thermal comfort to determine the best AC operational profile, including the temperature setpoint. Tang et al. (2017) highlighted that the average dry bulb temperature of Kuala Lumpur at 7:00 am is $26^{\circ} \mathrm{C}$ and subsequently increase and peak at $31.5^{\circ} \mathrm{C}$ at around $3: 00 \mathrm{pm}$ before going back down to $28^{\circ} \mathrm{C}$ at $6: 00 \mathrm{pm}$ and further down to $25^{\circ} \mathrm{C}$ by midnight. These data were based on 21 years of weather data from the Malaysian Meteorological Station in Subang, Klang Valley, Selangor. This explanation indicates the trend of low and high air temperature within a day, which can be mapped to the prayer times. For example, during Zohor prayer (after midday), the air temperature is uncomfortably high. However, the temperature during Subuh (dawn) is within an acceptable thermal range. The air temperature decreases during Asar (afternoon) and further down until Isyak (nighttime). Therefore, with an appropriate AC operational profile strategy, thermal comfort can be achieved during prayer times.

With the understanding of the air temperature and acceptable thermal comfort, Table 6 (top half) shows the baseline and proposed operational profiles $(1 \mathrm{~A}-1 \mathrm{~F})$ for both selected mosques. The columns marked with $(\sqrt{ })$ follows the time of the baseline profile (existing profile). In contrast, those marked with $(\mathrm{X})$ indicates no air-conditioning was operated during that particular period. Under the proposed operation profile, the new AC operation duration is stated in relevant columns using a 24-hour time format. The adjustments of AC operation times were made by considering the air temperature profile and the time needed to cool down spaces.

Table 6 : Simulation results based on different operational profiles at $19^{\circ} \mathrm{C}$ temperature setpoint for Wangsa Melawati Mosque (A1) and UTM Mosque (B2)

\begin{tabular}{|c|c|c|c|c|c|c|c|}
\hline Operation profile & Baseline & $1 A$ & $1 B$ & $1 C$ & $1 D$ & $1 E$ & $1 F$ \\
\hline $\begin{array}{l}\text { Setting Cooling } \\
\text { point }\end{array}$ & $19^{\circ} \mathrm{C}$ & $19^{\circ} \mathrm{C}$ & $19^{\circ} \mathrm{C}$ & $19^{\circ} \mathrm{C}$ & $19^{\circ} \mathrm{C}$ & $19^{\circ} \mathrm{C}$ & $19^{\circ} \mathrm{C}$ \\
\hline \multicolumn{8}{|l|}{ Subuh } \\
\hline $\begin{array}{l}\text { Daily/Friday/ } \\
\text { Ramadhan } \\
0530-0630\end{array}$ & $\sqrt{ }$ & $\mathrm{X}$ & $\mathrm{X}$ & $\mathrm{X}$ & $\mathrm{X}$ & $\mathrm{X}$ & $\mathrm{X}$ \\
\hline \multicolumn{8}{|l|}{ Zohor } \\
\hline $\begin{array}{l}\text { Daily } \\
1230-1330\end{array}$ & $\sqrt{ }$ & $\sqrt{ }$ & $\sqrt{ }$ & $\sqrt{ }$ & $1300-1330$ & $\sqrt{ }$ & $1300-1330$ \\
\hline $\begin{array}{l}\text { Friday only } \\
1230-1500\end{array}$ & $\sqrt{ }$ & $\sqrt{ }$ & $\sqrt{ }$ & $\sqrt{ }$ & $\sqrt{ }$ & $\sqrt{ }$ & $1230-1430$ \\
\hline $\begin{array}{l}\text { Ramadhan only } \\
1230-1400\end{array}$ & $\sqrt{ }$ & $\sqrt{ }$ & $\sqrt{ }$ & $\sqrt{ }$ & $\sqrt{ }$ & $\sqrt{ }$ & $1300-1400$ \\
\hline \multicolumn{8}{|l|}{ Asar } \\
\hline $\begin{array}{l}\text { Daily/Friday/ } \\
\text { Ramadhan } \\
1600-1700\end{array}$ & $\sqrt{ }$ & $\sqrt{ }$ & $1630-1700$ & $1630-1700$ & $1630-1700$ & $1630-1700$ & $1630-1700$ \\
\hline \multicolumn{8}{|l|}{ Maghrib \&Isyak } \\
\hline $\begin{array}{l}\text { Daily /Friday } \\
\text { 1900-2100 }\end{array}$ & $\sqrt{ }$ & $\sqrt{ }$ & $\sqrt{ }$ & $\mathrm{X}$ & $\mathrm{X}$ & $1900-2030$ & $\mathrm{X}$ \\
\hline $\begin{array}{l}\text { Maghrib } \\
\text { Daily/Friday }\end{array}$ & $\mathrm{X}$ & $\mathrm{X}$ & $\mathrm{X}$ & $1900-1930$ & $1900-1930$ & $\mathrm{X}$ & $1900-1930$ \\
\hline \multicolumn{8}{|l|}{ Isyak } \\
\hline Daily/Friday & $\mathrm{X}$ & $\mathrm{X}$ & $\mathrm{X}$ & $2000-2030$ & $2000-2030$ & $\mathrm{X}$ & $2000-2030$ \\
\hline
\end{tabular}




\begin{tabular}{|c|c|c|c|c|c|c|c|}
\hline \multicolumn{8}{|l|}{ Total energy } \\
\hline $\begin{array}{l}\text { Wangsa Melawati } \\
\text { Mosque (A1) }\end{array}$ & 119,343 & 114,939 & 110,871 & 105,918 & 102,205 & 107,646 & 101,323 \\
\hline $\begin{array}{l}\text { UTM Mosque } \\
\text { (B2) }\end{array}$ & 171,269 & 159,113 & 154,767 & 148,539 & 143,717 & 149,545 & 142,904 \\
\hline \multicolumn{8}{|l|}{$\begin{array}{l}\text { Total BEI } \\
\left(\mathrm{kWh} / \mathrm{yr} / \mathrm{m}^{2}\right)\end{array}$} \\
\hline $\begin{array}{l}\text { Wangsa Melawati } \\
\text { Mosque (A1) }\end{array}$ & 216 & 208 & 201 & 192 & 185 & 195 & 184 \\
\hline $\begin{array}{l}\text { UTM Mosque } \\
\text { (B2) }\end{array}$ & 186 & 173 & 168 & 161 & 156 & 162 & 155 \\
\hline \multicolumn{8}{|l|}{ Cost Index (RM) } \\
\hline $\begin{array}{l}\text { Wangsa Melawati } \\
\text { Mosque (A1) }\end{array}$ & 60,901 & 58,619 & 56,544 & 54,018 & 52,124 & 54,899 & 51,674 \\
\hline $\begin{array}{l}\text { UTM Mosque } \\
\text { (B2) }\end{array}$ & 87,347 & 81,147 & 78,930 & 75,754 & 73,295 & 76,267 & 72,881 \\
\hline \multicolumn{8}{|l|}{$\%$ Saving in BEI } \\
\hline $\begin{array}{l}\text { Wangsa Melawati } \\
\text { Mosque (A1) }\end{array}$ & - & 3.7 & 6.9 & 11.1 & 14.4 & 9.7 & 14.8 \\
\hline $\begin{array}{l}\text { UTM Mosque } \\
\text { (B2) }\end{array}$ & & 6.9 & 9.7 & 13.4 & 16.1 & 12.9 & 16.7 \\
\hline \multicolumn{8}{|l|}{$\%$ Saving in Cost } \\
\hline $\begin{array}{l}\text { Wangsa Melawati } \\
\text { Mosque (A1) }\end{array}$ & - & 3.7 & 7.2 & 11.3 & 14.4 & 9.9 & 15.2 \\
\hline $\begin{array}{l}\text { UTM Mosque } \\
\text { (B2) }\end{array}$ & - & 7.1 & 9.6 & 13.3 & 16.1 & 12.7 & 16.6 \\
\hline
\end{tabular}

Notes :

$(\sqrt{ })$ indicates that the air conditioner is operated during that prayer time using the existing profile.

( $\mathrm{X}$ ) indicates that the air conditioner is not operated.

The exchange rate of Malaysia Ringgit to U.S. Dollars is 0.24 (as of 9 August 2021)

: Amended operation profile from existing.

\subsection{Building Energy Simulation Result on Operational Profiles}

Using the baseline temperature setpoint of $19^{\circ} \mathrm{C}$, both mosques were simulated using six different operational profiles, labelled as "1A to $1 \mathrm{~F}$ ". The results presented in Table 7 (bottom half) show that the operational profile $1 \mathrm{~F}$ produced lower BEI for UTM Mosque $\left(155 \mathrm{kWh} / \mathrm{yr} / \mathrm{m}^{2}\right)$ than Wangsa Melawati Mosque $\left(184 \mathrm{kWh} / \mathrm{yr} / \mathrm{m}^{2}\right)$. The BEI percentage reduction for UTM Mosque and Wangsa Melawati Mosque was $16.7 \%$ and $14.8 \%$, respectively, while the cost-saving percentage was $16.6 \%$ for UTM and $15.2 \%$ for Wangsa Melawati Mosque.

Table 7 : Simulation results based on $1 \mathrm{~F}$ operational profile with different temperature setpoints for Wangsa Melawati Mosque (A1) and UTM Mosque (B2)

\begin{tabular}{l|c|c|cccc}
\hline & Existing & Alternative & \multicolumn{4}{|c}{ Different setpoint with 1F operational profile } \\
\hline Operation profile & Baseline & $1 \mathrm{~F}$ & 2 & 3 & 4 & 5 \\
\hline Setting Cooling point & $19^{\circ} \mathrm{C}$ & $19^{\circ} \mathrm{C}$ & $24^{\circ} \mathrm{C}$ & $25^{\circ} \mathrm{C}$ & $26^{\circ} \mathrm{C}$ & $27^{\circ} \mathrm{C}$ \\
\hline A1: Wangsa Melawati Mosque \\
\hline \multicolumn{7}{|l|}{} \\
\hline Total energy (kW) & 119,343 & 101,323 & 97,441 & 96,656 & 95,876 & 95,146 \\
\hline $\begin{array}{l}\text { Total BEI } \\
\left(\mathrm{kWh} / \mathrm{yr} / \mathrm{m}^{2}\right)\end{array}$ & 216 & 184 & 177 & 176 & 174 & 172 \\
\hline Energy Saving (\%) & - & 14.8 & 18.1 & 18.5 & 19.4 & 20.3 \\
\hline Cost (RM) & 60,901 & 51,574 & 49,694 & 49,294 & 48,896 & 48,524 \\
Saving in Cost (RM) & & 9327 & 11,207 & 11,607 & 12,005 & 12,377 \\
\hline
\end{tabular}

\section{B2: UTM Mosque}

30 Journal of Design and Built Environment, Vol 21(2) 19-38, August 2021 Mohamed et al. 


\begin{tabular}{l|c|c|cccc}
\hline Total energy $(\mathrm{kW})$ & 171,269 & 142,904 & 138,593 & 137,721 & 136,845 & 135,965 \\
\hline $\begin{array}{l}\text { Total BEI } \\
\left(\mathrm{kWh} / \mathrm{yr} / \mathrm{m}^{2}\right)\end{array}$ & 186 & 155 & 151 & 150 & 149 & 148 \\
\hline Energy Saving (\%) & - & 16.7 & 18.8 & 19.4 & 19.9 & 20.4 \\
\hline Cost (RM) & 87,347 & 72,881 & 70,682 & 70,237 & 69,790 & 69,342 \\
Saving in Cost (RM) & - & 14,466 & 16,665 & 17,110 & 17,557 & 18,005 \\
\hline
\end{tabular}

Note: The exchange rate of Malaysia Ringgit to U.S. Dollars is 0.24 (as of 9 August 2021)

Subsequently, further simulations were carried out on both mosques to investigate the energy impacts of $1 \mathrm{~F}$ operational profile and different temperature setpoints. The selected temperature setpoints were in the range of $24^{\circ} \mathrm{C}$ and $27^{\circ} \mathrm{C}$ based on the thermal comfort temperature recommended in MS1525 (Department of Standards Malaysia, 2019) and findings by Hussin et al. (2019). The operation considered the lighting profile, internal heat gains from equipment, such as fans and computers, and the occupants (i.e., full occupancy was assumed based on the cooling area). As shown in Table 7, a reduction in energy consumption and cost could be seen when $1 \mathrm{~F}$ operational profile was used. The range of energy and cost reductions for UTM Mosque were $18.8-20.4 \%$ and RM14,466.00$18,005.00$, respectively. For Wangsa Melawati Mosque, the range of energy reduction was 14.8$20.3 \%$, while the range of energy cost reduction was RM 9327.00-12,377.00.

\section{DISCUSSION}

The key results of this study are summarised in Table 8 . The table shows that only two out of six studied mosques had a BEI below the baseline level of $135 \mathrm{kWh} / \mathrm{m}^{2} / \mathrm{yr}$ as suggested by Hussin et al. (2019), namely A3 (Alam Damai Mosque) and B1 (Kota Damansara Mosque). The remaining four mosques with higher BEI than the baseline level of $200 \mathrm{kWh} / \mathrm{m}^{2} / \mathrm{yr}$ as in MS1525 (2019) were A1 (Wangsa Melawati Mosque), A2 (Bandar Baru Ampang Mosque), B2 (UTM Mosque), and B3 (Hidayah Mosque) with a respective BEI of $230 \mathrm{kWh} / \mathrm{m}^{2} / \mathrm{yr}, 151$ $\mathrm{kWh} / \mathrm{m}^{2} / \mathrm{yr}, 191 \mathrm{kWh} / \mathrm{m}^{2} / \mathrm{yr}$ and $152 \mathrm{kWh} / \mathrm{m}^{2} / \mathrm{yr}$. These mixed results between mosques in group A (with HVLS fans) and group B (without HVLS fans) do not clearly show the superiority of one group over the other in terms of energy performance. This indicates that mosques equipped with an HVLS fan may or may not consume more energy than mosques without any HVLS fan.

Table 8 : Summary of key results

\begin{tabular}{|c|c|c|c|c|}
\hline \multirow[b]{3}{*}{ MOSQUES } & \multicolumn{4}{|c|}{ BEI $\left(\mathrm{kWh} / \mathrm{m}^{2} / \mathrm{yr}\right)$} \\
\hline & \multirow{2}{*}{$\begin{array}{c}\text { Statistical } \\
\text { analysis (SPSS) } \\
\text { of } 2 \text {-year } \\
\text { electricity bills }\end{array}$} & \multicolumn{3}{|c|}{ Simulations (IESVE) } \\
\hline & & $\begin{array}{c}\text { Adjusted } \\
\text { Setpoints } \\
\text { Temp. }\left(27^{\circ} \mathrm{C}\right)\end{array}$ & $\begin{array}{l}\text { Operational } \\
\text { profile }(1 \mathrm{~F})\end{array}$ & $\begin{array}{c}\text { Setpoints Temp. }\left(27^{0} \mathrm{C}\right) \\
\text { and operational profile } \\
(1 \mathrm{~F})\end{array}$ \\
\hline \multicolumn{5}{|l|}{ MOSQUE WITH HVLS FAN } \\
\hline A1: Wangsa Melawati Mosque & 230 & 206 & 184 & 172 \\
\hline A2: Bandar Baru Ampang Mosque & 151 & & & \\
\hline A3: Alam Damai Mosque & 111 & & & \\
\hline \multicolumn{5}{|l|}{ MOSQUE WITHOUT HVLS FAN } \\
\hline B1:Kota Damansara Mosque & 133 & & & \\
\hline B2: UTM Mosque & 191 & 179 & 155 & 148 \\
\hline B3:Hidayah Mosque & 152 & & & \\
\hline
\end{tabular}

The mosques ranked first (A3: Alam Damai Mosque) and last (A1: Wangsa Melawati Mosque) in terms of energy consumption and electricity cost were those with HVLS fan. This result does not support the notion that using a ceiling fan in an air-conditioned area should help reduce building energy consumption (Shah et al., 2015). The observation found that Wangsa Melawati Mosque used the HVLS fan while maintaining the $\mathrm{AC}$ temperature setpoint at a minimum of $19^{\circ} \mathrm{C}$. The reason for this was that the air conditioners in the main prayer hall were undersized; thus, a setting of $19^{\circ} \mathrm{C}$ was done to help cooling down the hall faster. Research has shown that $\mathrm{AC}$ temperature setpoints of $26^{\circ} \mathrm{C}$ to $28^{\circ} \mathrm{C}$ are more comfortable when a fan is provided than a temperature of $24^{\circ} \mathrm{C}$ without a fan (Zhai et al., 2019). Furthermore, the combination

31 Journal of Design and Built Environment, Vol 21(2) 19-38, August 2021 Mohamed et al. 
of air movement from the fan and the air conditioners help to shorten the period to cool down the temperature. Indeed, using both HVLS fan and air conditioners can reduce the building energy consumption if the $\mathrm{AC}$ temperature setpoint is increased to a certain degree.

The best profile of operating air-conditioners and fans simultaneously to avoid energy wastage is essential for building operators to consider. Wai et al. (2015) pointed out that understanding how the cooling device work can reduce power consumption. Since mosques are unique in terms of function and operation, building operators need to understand the mosques' occupancy profile to monitor and control the building energy usage, mainly when the occupancy level is high.

The study's simulation results indicate that a combination strategy of temperature setpoint and operational profile adjustments can produce energy- and cost-savings. The study found that both studied mosques could produce around 1$4.9 \%$ energy reduction when the $\mathrm{AC}$ temperature setpoint was increased by $1{ }^{\circ} \mathrm{C}$ and could result in the highest cost-saving of about RM3,456.00 when the temperature was set at $27^{\circ} \mathrm{C}$. This finding is in line with Armin and Sarip (2016), who proved that reducing $\mathrm{AC}$ temperature by $1^{\circ} \mathrm{C}$ could result in a $4-5 \%$ increment of building energy consumption and the highest consumption, about $40 \%$ when the temperature was set at $19.89^{\circ} \mathrm{C}$. Since the temperature setpoint directly impacts energy consumption, it is vital to look into occupants behaviour, particularly in terms of AC temperature settings and duration of usage (Yan et al., 2019a). Indeed, adjustments to higher AC temperature setpoints are effective for energy savings (Wang et al., 2013).

Unlike office buildings with a fixed operational profile of 9:00 am to 5:00 pm, mosques' operational profile is based on prayer times. By linking these prayer times with the local annual air temperature, one can estimate the duration required to run the AC. For example, data from the Malaysian Meteorological Department presented in Tang et al., (2017) highlighted that the daily average, maximum, and minimum dry bulb temperature of Kuala Lumpur. A strategy for $\mathrm{AC}$ operation for each daily prayer time was developed for energy efficiency guided by these weather data. For instance, during Subuh prayer time, which usually begins between 5:00 am to 6:00 am (Malaysia time zone), the average air temperature is $24^{\circ} \mathrm{C}$, as shown in Figure 3. This temperature falls within an acceptable thermal range; hence, it is sensible to suggest that $\mathrm{AC}$ 's operation is not required during this time. AC system operation may be necessary during Zohor prayer time, which is around $12: 30 \mathrm{pm}$ to $2: 00 \mathrm{pm}$ since the average air temperature is as high as $31^{\circ} \mathrm{C}$.

However, it is also important to consider the duration of the AC operation. The current AC operation during weekly Friday prayer, which is performed at Zohor time from 12:00 pm to 3:00 $\mathrm{pm}$, is acceptable as the air temperature is high, and occupants stay longer in the mosque compared to everyday Zohor prayer. During Asar prayer, which is generally performed between 4:00 pm to 5:00 pm, it is essential to operate the $\mathrm{AC}$ as the average temperature is around $28^{\circ} \mathrm{C}$. During Maghrib and Isyak prayers, the operation of the AC system may need to be reconsidered as the temperature during these hours is at $26^{\circ} \mathrm{C}$. During the daytime in the Ramadhan month, $\mathrm{AC}$ systems are typically run from 1:00 pm to 2:00 $\mathrm{pm}$, which is acceptable considering the high air temperature. Furthermore, many activities (e.g. itiqaf) are held during this time that attracts worshippers to spend a longer time at the mosque. During Maghrib and Isyak times in the Ramadhan month, the AC system is necessary as worshippers tend to stay for long hours in the mosque to perform three prayers almost consecutively (i.e. Maghrib, Isyak, and Taraweh).

From the foregoing discussion, it appears that the AC system operation is necessary during every prayer time except for Subuh, during which the air temperature is acceptable for thermal comfort. Notably, however, the duration required for the $\mathrm{AC}$ to run during each prayer session needs to be further analysed to avoid energy wastage. The study revealed that mosques operated their AC systems every day for 30 minutes during Subuh prayer, 1 hour each for Zohor and Asar; and a continuous operation during Maghrib and Isyak. Furthermore, the mosques ran their AC systems for 2.5 hours during weekly Friday prayers and 4 hours during Maghrib and Isyak prayers in the month of Ramadhan. The study argues that these baseline operational profiles could be adjusted for energy efficiency.

Therefore, a few simulations were performed on two mosques ranked lowest in energy consumption and cost using a $19^{\circ} \mathrm{C}$ temperature setpoint to investigate the impacts of using different operational profiles (labelled as $1 \mathrm{~A}$ to $1 F)$ building energy consumption. As shown in Table 7, operation profile $1 \mathrm{~F}$ produced the highest reduction in BEI for both mosques: 184 $\mathrm{kWh} /$ year/ $\mathrm{m}^{2}$ for Wangsa Melawati Mosque (A1) and $155 \mathrm{kWh} /$ year $/ \mathrm{m}^{2}$ for UTM Mosque (B2). The research evidence indicates that the most efficient daily $\mathrm{AC}$ operation profile is to use the AC system for 30 minutes during Zohor, Asar, Maghrib and Isyak, and leave the mosque naturally ventilated during Subuh prayer. Instead 
of continuously operating the AC system from Maghrib to Isyak, as currently practised, it would be more efficient to operate for 30 minutes during Maghrib, and 30 minutes during Isyak. The study also demonstrates that it is more energy efficient to shorten the AC operation for 30 minutes during Friday prayers, i.e. to end at 14:30 hour instead of 15:00 hours. For the Ramadhan month, the study suggests that the AC operation time be 1 hour during Zohor time but reduced from 4 to 3 hours during nighttime.

A 30-minute duration for AC operation is enough to cool down mosque spaces. Previous studies have confirmed that it takes 15 minutes for the $\mathrm{AC}$ system to operate before the prayer time to allow pre-cooling of the space, and the next 15 minutes during the prayer time is adequate to remove the indoor warm air (Stadler et al., 2009; Wai et al., 2015; Welguisz et al., 1998). The 15minute duration is assumed as the air temperature supply factor where the constant air volume meets the cooling load in the occupied zone (Cheng et al., 2018). Furthermore, the daily prayer time lasts about 15 minutes from the start of Azan (AlHomoud et al., 2005a). Once the prayer is completed, the indoor air temperature can last for another 10-15 minutes after the air-conditioner is turned off, assuming the AC system's ideal cycle.

Still using the operation profile $1 \mathrm{~F}$ as the baseline, further simulations were conducted on the studied mosques by incorporating the temperature setpoints within the thermal comfort range as recommended in the Malaysia Standard MS 15252:2019, and Hussin et al. (2014). Table 7 presents the summary of the results with temperature setpoints between $24^{\circ} \mathrm{C}$ and $27^{\circ} \mathrm{C}$. These recommended four temperature setpoints produced an energy savings range of $14.8 \%$ to $20.4 \%$ and cost savings of between RM12,377.00 to RM18,005.00. These findings support earlier findings that suggest the temperature range of between $24^{\circ} \mathrm{C}$ to $27^{\circ} \mathrm{C}$ is acceptable for thermal comfort in hot and humid climates (Djamila et al., 2013; Khalid et al., 2019). Although this study revealed that $27^{\circ} \mathrm{C}$ of $\mathrm{AC}$ temperature setting produced the highest reduction in BEI (average $20 \%$ energy saving and $20 \%$ cost saving), mosque operators can adjust the temperature setpoint according to the thermal preference of the worshippers. From the results of the Wangsa Melawati Mosque and UTM Mosque simulations, a temperature setpoint of $27^{\circ} \mathrm{C}$ produced a BEI of $172 \mathrm{kWh} / \mathrm{yr} / \mathrm{m}^{2}$ and $148 \mathrm{kWh} / \mathrm{yr} / \mathrm{m}^{2}$, respectively. These values are lower than $200 \mathrm{kWh} / \mathrm{yr} / \mathrm{m}^{2}$ in MS1525:2019 and $181.9 \mathrm{kWh} / \mathrm{yr} / \mathrm{m}^{2}$ in $\mathrm{Al}-$ Homoud et al. (2005b).

Concerning the simultaneous usage of $\mathrm{AC}$ and HVLS fans, the study recommends the following measures:

- AC temperature setpoints: AC system consumes less energy when the temperature setting is higher. Understanding the optimum AC temperature setting when an HVLS fan is operated together is vital to avoid energy wastage without compromising the occupants' thermal comfort. It is worth considering the 10-minute cycle time for the AC system to cool down spaces before the prayer begins to have better indoor thermal comfort (Mustapa et al., 2017; Papadopoulos et al., 2019).

- Building operation profile: Mosque operates according to prayer time; hence, the operation of mechanical ventilation should follow the prayer time. Dry bulb air temperature should be considered in the operation setting (temperature and timing) of the mechanical ventilation system (Budaiwi \& Abdou, 2013)

- Energy management knowledge of building operators: The government should initiate educational programmes (e.g. practical training or short seminars) for mosque operators, especially those with no technical background, such as mosque officers. Such programmes would allow them to enhance their knowledge of the proper handling of the mechanical ventilation system to achieve energy efficiency. A standard operating procedure (SOP) or guideline would be useful for them (Hussin et al., 2014)

- Equipment performance: Designer and maintenance personnel should be trained better to understand the types of air conditioners and fans to avoid installing undersized or oversized equipment, which would result in high energy consumption (Shah et al., 2015). For HVLS fan, the size and motor efficiency should be considered. While the fan's air movement contributes to occupants' comfort, its usage does not reduce the ambient temperature. The type of blade, dimension and fan speed play an essential role in air distribution (Othman et al., 2019; Zhai et al., 2019).

\section{CONCLUSION}

This study has revealed the energy consumption patterns of six studied air-conditioned mosques, with and without HVLS fan installed. Integration of an HVLS fan in an air-conditioned mosque can reduce the building energy consumption without compromising the occupants' thermal comfort if both systems are operated optimally through proper temperature setpoints and operational profiles. This study has shown that increasing the AC temperature by $1{ }^{\circ} \mathrm{C}$ could result in $1-4.9 \%$ energy saving. A 30-minute AC operation during 
each daily prayer (except Subuh) could achieve $14.8-16.7 \%$ annual energy saving and about 15.2$16.6 \%$ annual energy cost. This study has also shown that a combined strategy of adjusting the $\mathrm{AC}$ thermostat setting between $24-27^{\circ} \mathrm{C}$ and operating the $\mathrm{AC}$ for 30 minutes at every prayer time (but no AC operation during Subuh prayer) can produce up to $20 \%$ energy saving. In other words, the adjustment of temperature setpoints alone will reduce minimal energy consumption. The combined strategies of appropriate temperature setpoints and building operational profiles are vital to maximising energy efficiency and minimising energy cost without compromising the occupant's thermal comfort.

\section{LIMITATION AND RECOMMENDATION}

Since this study focuses on mosque buildings with intermittent occupancy, the results may not apply to other building types with predictable occupancies, such as commercial buildings. Another limitation is that the study did not consider the future weather profiles, as climate change will affect the air temperature. One potential extension of this study is to obtain the mosques' detail monitoring energy data, including their indoor air temperatures, to optimise the mosques' setpoint temperatures. The study recommends these outcomes be considered in the energy management guidelines for mosque buildings in Kuala Lumpur. Relevant educational programmes for mosque operators, especially those without any technical background, are vital to lowering mosques' energy consumption while maintaining indoor thermal comfort.

\section{ACKNOLEDGEMENTS}

A special thanks to Ustaz Azahari from the Wangsa Melawati mosque and the Department of Asset \& Development staff, Universiti Teknologi Malaysia (UTM) Kuala Lumpur, for giving permission to conduct this research at the selected mosques.

\section{REFERENCES}

[1] Aghniaey, S., \& Lawrence, T. M. (2018). The impact of increased cooling setpoint temperature during demand response events on occupant thermal comfort in commercial buildings: A review. Energy \& Buildings, 173, 1927.

https://doi.org/10.1016/j.enbuild.2018.0 4.068

[2] Al-Homoud, M.,Abdou, A., \& Budaiwi, I. (2005a). Mosque energy performance, part I : energy audit and use trends based on the analysis of utility billing data. Journal King Abdulaziz University: Engineering and Science, 16(January), 165-184.

https://doi.org/10.4197/Eng.16-1.10

[3] Al-Homoud, M., Abdou, A., \& Budaiwi, I. (2005b). Mosque energy performance, part II : monitoring of energy end use in a hot-humid climate. JKAU: Eng. Sci., 16(1), 185-202.

[4] Al-Homoud, M., Abdou, A., \& Budaiwi, I. (2009). Assessment of monitored energy use and thermal comfort conditions in mosques in hot-humid climates. Energy \& Buildings, 41, 607614.

https://doi.org/10.1016/j.enbuild.2008.1 2.005

[5] Al-shaalan, A. M., \& Alohaly, A. H. A. (2017). Design strategies for a big mosque to reduce electricity consumption in the Kingdom of Saudi Arabia. The 21st World MultiConference on Systemics, Cybernetics and Information, Wmsci, 313-317.

[6] Ali, H., \& Hashlamun, R. (2019). Envelope retrofitting strategies for public school buildings in Jordan. Journal of Building Engineering, 25(May), 100819. https://doi.org/10.1016/j.jobe.2019.100 819

[7] Ariosto, T., Memari, A. M., \& Solnosky, R. L. (2019). Development of designer aids for energy efficient residential window retrofit solutions. Sustainable Energy Technologies and Assessments, 33(February), $1-13$. https://doi.org/10.1016/j.seta.2019.02.0 07

[8] Ascione, F., Bianco, N., De Masi, R. F., Mastellone, M., Mauro, G. M., \& Vanoli, G. P. (2020). The role of the occupant behavior in affecting the feasibility of energy refurbishment of residential buildings: Typical effective retrofits compromised by typical wrong habits. Energy and Buildings, 223(2020), 110217. https://doi.org/10.1016/j.enbuild.2020.1 10217

[9] Atmaca, A. B., \& Gedik, G. Z. (2019). Evaluation of mosques in terms of thermal comfort and energy consumption in a temperate-humid climate. Energy \& Buildings, 195, 195204.

https://doi.org/10.1016/j.enbuild.2019.0 4.044

[10] Barthelmes, V. M., Becchio, C., Fabi, 
V., \& Corgnati, S. P. (2017). Occupant behaviour lifestyles and effects on building energy use: investigation on high and low performing building features. Energy Procedia, 140, 93-101. https://doi.org/10.1016/j.egypro.2017.1 1.126

[11] Brown, P., Swan, W., \& Chahal, S. (2014). Retrofitting social housing: Reflections by tenants on adopting and living with retrofit technology. Energy Efficiency, 7(4), 641-653. https://doi.org/10.1007/s12053-0139245-3

[12] Budaiwi, I., \& Abdou, A. (2013). HVAC system operational strategies for reduced energy consumption in buildings with intermittent occupancy: The case of mosques. Energy Conversion and Management, 73, 37-50. https://doi.org/10.1016/j.enconman.201 3.04 .008

[13] Cajot, S., Peter, M., Bahu, J. M., Guignet, F., Koch, A., \& Maréchal, F. (2017). Obstacles in energy planning at the urban scale. Sustainable Cities and Society, 30, 223-236. https://doi.org/10.1016/j.scs.2017.02.00 3

[14] Chen, W., Zhang, H., Arens, E., Luo, M., Wang, Z., Jin, L., Liu, J., Bauman, F. S., \& Raftery, P. (2020). Ceiling-fanintegrated air conditioning: Airflow and temperature characteristics of a sidewall-supply jet interacting with a ceiling fan. Building and Environment, 171 ,

$0-32$. https://doi.org/10.1016/j.buildenv.2020. 106660

[15] Cheng, Y., Yang, B., Lin, Z., Yang, J., \& Du, Z. (2018). Cooling load calculation methods in spaces with stratified air: A brief review and numerical investigation. Energy \& Buildings, 165, $47-55$.

https://doi.org/10.1016/j.enbuild.2018.0 1.043

[16] Dall'O', G., Sarto, L., Galante, A., \& Pasetti, G. (2012). Comparison between predicted and actual energy performance for winter heating in high-performance residential buildings in the Lombardy region (Italy). Energy and Buildings, 47, 247-253

https://doi.org/10.1016/j.enbuild.2011.1 1.046

[17] Department of Islamic Development Malaysia. (2020). List of mosques in Malaysia. http://www.islam.gov.my/masjidputra/1243-profil
[18] Department of Standards Malaysia. (2014). Architecture and asset management of masjid-code of practice (MS2577:2014). Department of Standards Malaysia.

[19] Department of Standards Malaysia. (2019). Energy efficiency and use of renewable energy for non-residential buildings- code of practice (M.S.1525: 2019). Department of Standard Malaysia.

[20] Department of Statistic Malaysia. (2019). Current population estimates, Malaysia [Press release] (Issue 15 July, pp. 1-4). https://www.dosm.gov.my/v1/index.ph $\mathrm{p}$

[21] Djamila, H., Chu, C. M., \& Kumaresan, S. (2013). Field study of thermal comfort in residential buildings in the equatorial hot-humid climate of Malaysia. Building and Environment, 62, 133-142. https://doi.org/10.1016/j.buildenv.2013. 01.017

[22] Fang, Y., \& Cho, S. (2019). Design optimisation of building geometry and fenestration for daylighting and energy performance. Solar Energy, 191(August), 7-18. https://doi.org/10.1016/j.solener.2019.0 8.039

[23] Friedman, C., Becker, N., \& Erell, E. (2014). Energy retrofit of residential building envelopes in Israel: A costbenefit analysis. Energy, 77, 183-193. https://doi.org/10.1016/j.energy.2014.0 6.019

[24] Hamzah, B., Kusno, A., \& Mulyadi, R. (2018). Design of energy efficient and thermally comfortable air-conditioned university classrooms in the tropics. International Journal of Sustainable Energy.

[25] Hawaii Natural Energy Institute. (2017). Ceiling fan study: literature and market report (Issue August)

[26] Ho, K., Hoyt, T., Lee, K. H., Zhang, H., \& Arens, E. (2009). Energy savings from extended air temperature setpoints and reduction in room air mixing. International Conference on Environmental Ergonomics 2009, Boston, U.S.A.

[27] Hui, H., Ding, Y., Liu, W., Lin, Y., \& Song, Y. (2017). Operating reserve evaluation of aggregated air conditioners. Applied Energy, 196, 218 228.

[28] Hussin, A, Salleh, E., Chan, H. Y., \& Mat, S. (2014). Thermal comfort during daily prayer times in an air-conditioned 
mosque in Malaysia. Proceedings of 8th Windsor Conference: Counting the Cost of Comfort in a Changing World, April, 10-13.

[29] Hussin, Azman, Chin Haw, L., \& Salleh, E. (2019). Air conditioning energy profile and intensity index for retrofitted mosque building: a case study In Malaysia. Alam Cipta, 12(1), 17-27.

[30] Ibrahim, A. (2015). Sustainable design strategy: assessment of the impact of design variables on energy consumption of office buildings in Abuja, Nigeria. University of Portsmouth.

[31] Jami, S., Forouzandeh, N., Zomorodian, Z. S., Tahsildoost, M., \& Khoshbakht, M. (2020). The effect of occupant behaviors on energy retrofit: A case study of student dormitories in Tehran. Journal of Cleaner Production, 278, 123556

https://doi.org/10.1016/j.jclepro.2020.1 23556

[32] Jankovic, L. (2019). Lessons learnt from design, off-site construction and performance analysis of deep energy retrofit of residential buildings. Energy and Buildings, 186, 319-338. https://doi.org/10.1016/j.enbuild.2019.0 1.011

[33] Khalid, W., Zaki, S. A., Rijal, H. B., \& Yakub, F. (2019). Investigation of comfort temperature and thermal adaptation for patients and visitors in Malaysian hospitals. Energy and Buildings, 183, 484-499. https://doi.org/10.1016/j.enbuild.2018.1 1.019

[34] Knight, I. P. (2016). Operational energy use and power demands in European HVAC components. Building Services Engineering Research and Technology, $37(2)$, 148-162. https://doi.org/10.1177/0143624415613 954

[35] Li, H. X., Li, Y., Jiang, B., Zhang, L., Wu, X., \& Lin, J. (2020). Energy performance optimisation of building envelope retrofit through integrated orthogonal arrays with data envelopment analysis. Renewable Energy, 149, 14141423.

https://doi.org/10.1016/j.renene.2019.10 .143

[36] Malaysia Economic Planning Unit. (2015). Guideline and requirement for building planning. Malaysia Prime Minister Department.

[37] Malaysia Energy Commission. (2019). Handbook Malaysia energy statistics 2019 annual report.
[38] Malaysia Meteorological Department. (2019). Malaysian meteorological department 2019 annual report.

[39] Mancini, F., \& Nastasi, B. (2019). Energy retrofitting effects on the energy flexibility of dwellings. Energies, 12(14).

https://doi.org/10.3390/en12142788

[40] Mcknight, T. L., \& Hess, D. (2000). Physical Geography- A landscape appreciation (6th ed.). Prentice-Hall.

[41] Mirakyan, A., \& De Guio, R. (2013). Integrated energy planning in cities and territories: A review of methods and tools. Renewable and Sustainable Energy Reviews, 22, 289-297. https://doi.org/10.1016/j.rser.2013.01.0 33

[42] Moghimi, S., Mat, S., Lim, C. H., Zaharim, A., \& Sopian, K. (2011). Building energy index ( BEI) in large scale hospital : case study of Malaysia. Recent Researches in Geography, Geology, Energy, Environment and Biomedicine, 167-170.

[43] Mohamad, N. L., Shari, Z., \& Dahlan, N. D. (2018). Building envelope retrofit: enhancing energy performance in existing government office buildings in Malaysia. Malaysia University-Industry Green Building Collaboration Symposium, 1, 285-293.

[44] Mohd Safaai, N. S., Hashim, H., Noor, Z. Z., \& Talib, J. (2011). Projection of $\mathrm{co} 2$ emissions in Malaysia. Environmental Progress \& Sustainable Energy, 33(3), 676-680. https://doi.org/10.1002/ep

[45] Moshfeghi, M., Hur, N., Kim, Y. J., Kang, H. W., \& Moshfeghi, M. (2014). An Investigation on HVLS fan performance with different blade configurations. Journal Computer Fluid Engineering, 19(4), 80-85.

[46] Mustapa, M. S., Shaikh Salim, S. A. Z., \& Mat Ali, M. S. (2017). Investigation of thermal comfort at different temperature settings for cooling in university building. Journal of Mechanical Engineering, 4(4), 123-134.

[47] Omar, N. A. A., Joharudin, N. F. M., Ahmad, A. Z. S., Noranai, Z., Batcha, M. F. M., \& Taweekun, J. (2020). Energy consumption and potential saving in MSI complex. Journal of Advanced Research in Fluid Mechanics and Thermal Sciences, 68(2), 145-151. https://doi.org/10.37934/ARFMTS.68.2 .145151

[48] Othman, R. N. F. K. R., Abdullah, N., Ahamat, A., Zuki, N. A. M., Shukor, F. 
A. A., \& Karim, K. A. (2019). Assessing monstrous fan in Malaysia: Present and future. Journal of Open Innovation: Technology, Market, and Complexity, $5(1)$. https://doi.org/10.3390/joitmc5010014

[49] Pan, S., Wang, X., Wei, S., Xu, C., Zhang, X., Xie, J., Tindall, J., \& De Wilde, P. (2017). Energy waste in buildings due to occupant behaviour. Energy Procedia, 105(0), 2233-2238. https://doi.org/10.1016/j.egypro.2017.0 3.636

[50] Papadopoulos, S., Kontokosta, C. E., Vlachokostas, A., \& Azar, E. (2019). Rethinking HVAC temperature setpoints in commercial buildings: the potential for zero-cost energy savings and comfort improvement in different climates. Building and Environment, 155(April), 350-359. https://doi.org/10.1016/j.buildenv.2019. 03.062

[51] Rogeau, A., Girard, R., Abdelouadoud, Y., Thorel, M., \& Kariniotakis, G. (2020). Joint optimisation of buildingenvelope and heating-system retrofits at territory scale to enhance decisionaiding. Applied Energy, 264(January), 114639.

https://doi.org/10.1016/j.apenergy.2020. 114639

[52] Saidur, R., \& Masjuki, H. H. (2008). Energy and associated emission analysis In office buildings. Mechanical and Materials Engineering, 3(1), 90-96.

[53] Sánka, I., \& Petráš, D. (2019). Energy conservation by retrofitting of dwellings. E3S Web of Conferences, 111(201 9), 2-6. https://doi.org/10.1051/e3sconf/201911 103010

[54] Somasundaram, S., Thangavelu, S. R., \& Chong, A. (2020). Improving building efficiency using low-e coating based retrofit double glazing with solar films. Applied Thermal Engineering, 171(August 2019). https://doi.org/10.1016/j.applthermalen g.2020.115064

[55] Stadler, M., Krause, W., Sonnenschein, M., \& Vogel, U. (2009). Modelling and evaluation of control schemes for enhancing load shift of electricity demand for cooling devices. Environmental Modelling and Software, 24(2), 285-295. https://doi.org/10.1016/j.envsoft.2008.0 7.003

[56] Sunardi, C., Hikmat, Y. P., Margana, A. S., Sumeru, K., \& Sukri, M. F. (2020).
Effect of room temperature set points on energy consumption in a residential air conditioning. Thermofluid $X$ : 10th International Conference on Thermofluids 2019, Yogyakarta, Indonesia.

[57] Tahsildoost, M., \& Zomorodian, Z. S. (2015). Energy retrofit techniques: An experimental study of two typical school buildings in Tehran. Energy and Buildings, 104, 65-72. https://doi.org/10.1016/j.enbuild.2015.0 6.079

[58] Tang, C., Chin, N., Guan, Y. T., \& Misara, S. (2017). Building energy efficiency technical guideline for active design. Printmore Sdn Bhd.

[59] Tom, S. (2008). Managing energy and comfort: don't sacrifice comfort when managing energy. ASHRAE Journal, 50(60), 18-24.

[60] Tushar, W., Tao, W., Lan, L., Xu, Y., Withanage, C., Yuen, C., \& Wood, K. L. (2016). Policy design for controlling setpoint temperature of ACs in shared spaces of buildings. Energy \& Buildings, $1-19$.

[61] Wai, C. H., Beaudin, M., Zareipour, H., Schellenberg, A., \& Lu, N. (2015). Cooling devices in demand response : a comparison of control methods. IEEE Transactions On Smart Grid, 6(1), 249260.

[62] Wang, N., Zhang, J., \& Xia, X. (2013). Energy consumption of air conditioners at different temperature set points. Energy \& Buildings, 65(September), 412-418.

https://doi.org/10.1109/AFRCON.2011. 6072174

[63] Wang, P., \& Lin, J. (2013). Using smart controlled AC and ceiling fan to save energy. Computation and Performance, 2, 21-28.

[64] Welguisz, R. .., Guy, S. E., Taylor, J. T., \& Dunnellon, F. (1998). Method for controlling an air conditioning system for optimum humidity control. (Patent No. 5,743,100A). U.S. Patent and Trademark Office. https//:uspto.gov/5743100A

[65] Wu, R., Mavromatidis, G., Orehounig, K., \& Carmeliet, J. (2017). Multiobjective optimisation of energy systems and building envelope retrofit in a residential community. Applied Energy, 190, 634-649. https://doi.org/10.1016/j.apenergy.2016. 12.161

[66] Xia, D., Lou, S., Huang, Y., Zhao, Y., Li, D. H. W., \& Zhou, X. (2019). A study on 
occupant behaviour related to airconditioning usage in residential buildings. Energy \& Buildings, 203. https://doi.org/10.1016/j.enbuild.2019.1 09446

[67] Xu, P., Xu, T., \& Shen, P. (2013). Energy and behavioral impacts of integrative retrofits for residential buildings: What is at stake for building energy policy reforms in northern China? Energy Policy, 52, 667-676. https://doi.org/10.1016/j.enpol.2012.10. 029

[68] Yamtraipat, N., Khedari, J., \& Hirunlabh, J. (2005). Thermal comfort standards for air-conditioned buildings in hot and humid Thailand considering additional factors of acclimatisation and education level. Solar Energy, 78(4), 504-517.

[69] Yan, L., Liu, M., Xue, K., \& Zhang, Z. (2019a). A study on temperature-setting behavior for room air conditioners based on big data. Journal of Building Engineering, 30(March 2019), 101197. https://doi.org/10.1016/j.jobe.2020.101 197

[70] Yan, X., Liu, C., Li, M., Hou, A., Fan, K., \& Meng, Q. (2019b). Climate compensation and indoor temperature optimal measuring point energy saving control in VAV air-conditioning system. Energies, 12(22). https://doi.org/10.3390/en12224398

[71] Yang, Z., \& Becerik-gerber, B. (2014). The coupled effects of personalised occupancy profile based HVAC schedules and room reassignment on building energy use. Energy \& Buildings, 78, 113-122. https://doi.org/10.1016/j.enbuild.2014.0 4.002

[72] Yendo, A. E., Denny, M., Puad, A. M. S., Mahmud, M. J., \& Basri, I. (2015). An assessment of green mosque index in peninsular Malaysia. AmericanEurasian Journal Agriculture and Environmental Sciences (Tourism \& Environment, Social and Management Sciences), $\quad 15, \quad 114-122$. https://doi.org/10.5829/idosi.aejaes.201 5.15.s. 215

[73] Zhai, Y., Miao, F., Yang, L., Zhao, S., Zhang, H., \& Arens, E. (2019). Using personally controlled air movement to improve comfort after simulated summer commute. Building and Environment, 165(July), 106329. https://doi.org/10.1016/j.buildenv.2019. 106329 